\title{
ESI-MS を用いたケイ酸と金属イオンの反応機構の解明
}

\author{
有我 洋香 ${ }^{1}$, 田中 美穂 $^{* 1}$
}

\begin{abstract}
エレクトロスプレーイオン化質量分析法（ESI-MS）を用い, ケイ酸と金属イオンの錯体の溶存状態を正イ オン, 負イオンの両イオンについて観測した. 金属塩化物 $\left(\mathrm{MCl}_{2}\right)$ 溶液及びケイ酸と $\mathrm{MCl}_{2}$ の溶液において, 検出された化学種を比較し, ESI-MS 内における反応機構を推測した上で, 錯体の安定性について新たな情報 を得た．正イオンに扔いては，金属元素による加水分解のされやすさを示す結果が得られた. $\mathrm{MCl}_{2}$ 溶液にケ 洒夋を添加した溶液に扔いても，金属元素の加水分解のされやすさを反映した結果が得られ，さらに，2 族 元素間でケイ酸と錯形成しやすい元素が異なることを確認した．負イオンでは，カルシウムイオン $\left(\mathrm{Ca}^{2+}\right)$ 及びナトリウム $\left(\mathrm{Na}^{+}\right)$イオンとケイ酸の錯体が確認され，これらの元素とケイ酸の錯体は溶存化学種であ ると判断した．以上のことから，ケイ酸と金属イオンの錯体の安定性は金属イオンの大きさに依存し， $\mathrm{Ca}^{2+}$ 及び $\mathrm{Na}^{+}$との安定性が高いことを示唆する結果が得られた。
\end{abstract}

\section{1 緒言}

ケイ酸は溶液の濃度, $\mathrm{pH}$, 温度によってモノケイ酸, ポ リケイ酸，コロイド状シリカなど様々な化学形をとる．地 熱発電などに用いられる高温の天然水は，高温におけるケ イ酸の溶解度が高いために, ケイ酸を比較的多く溶解す る.この天然水は水温の低下とともに溶存態のケイ酸が重 合し，難溶性のケイ酸沈殿 [シリカ系スケール ; ナトリウ ム $(\mathrm{Na})$ ，カルシウム $(\mathrm{Ca})$, マグネシウム $(\mathrm{Mg})$ などを 含むケイ酸の沈殿］を形成する.これが輸送配管内に付着 することにより, 地熱発電の効率的な運転の妨げとなって いる。 これまで, 諸条件 (濃度, $\mathrm{pH}$, 温度) の変化による ケイ酸の化学形の変化について様々な研究がされてきた が, 地熱発電に用いられる天然水にはケイ酸以外にも様々 な元素が低濃度で含まれているので, ケイ酸のみの研究で は説明が困難である. 溶液中の金属を含むケイ酸の研究と しては，金属イオンによる溶存態のケイ酸の重合への影 響1 ${ }^{1}$ や,コロイド状シリカ ${ }^{2}$ やシリカゲル ${ }^{3)}$ への金属の吸着 などの研究がある. しかし, 溶液中のケイ酸と金属元素の 錯形成を含めた溶存状態についてはいまだ明らかにされて 抢らず, $\mathrm{Ca}$ や $\mathrm{Mg}$ などの天然水中に比較的多く存在する金 属イオンとケイ酸の錯形成の各過程を明らかにしていく必 要がある．したがって，ケイ酸と 1 族， 2 族などの金属元 素との錯体の反応性について研究を行うことにした.

河川水や地下水などの天然の水には, ケイ酸のほかに

\footnotetext{
*E-mail : mihotnk@kaiyodai.ac.jp

1 東京海洋大学大学院海洋科学技術研究科海洋環境保全学専攻: 108-8477 東京都港区港南 4-5-7
}

$\mathrm{Na}^{+}, \mathrm{Ca}^{2+}, \mathrm{Mg}^{2+}$ などが多く含まれているので，これらの イオンの濃度を考虑して, ケイ酸の錯体の安定性を検討す る必要がある。高濃度のケイ酸溶液中のケイ酸の溶存状態 分析の多くは ${ }^{29} \mathrm{Si}$ - 核磁気共鳴法 $(\mathrm{NMR})^{4) \sim 8)}$ を用いた研究 である。低濃度のケイ酸溶液に関しては，高速原子衝突質 量分析法 (FAB-MS $)^{9)}$ やエレクトロスプレーイオン化質量 分析法 $(\mathrm{ESI}-\mathrm{MS})^{10111}$ などの質量分析による報告もある. 天 然水のケイ酸濃度は, 数 $\mathrm{mmol} \mathrm{L}^{-1}$ 程度であり, ${ }^{29} \mathrm{Si}-\mathrm{NMR}$ で化学形を測定するには感度不足である。これまで, FAB-MS においてケイ酸の溶存化学種の測定を行ってきた が, ケイ酸は負イオンで検出され，1族，2族の金属イオン は正イオンで検出されるので, FAB-MS で一度に両イオン の情報を得ることは難しい，そこで本研究では， ESI-MSを 用いて, 溶液中のケイ酸と 1,2 族の金属の水和状態を含め た化学状態を正イオンと負イオンで測定することにした. 2 族の金属イオンの比較のために, 2 価の遷移金属とケイ 酸の反応も測定した. 天然水中の金属の濃度に対応し, $1 \mathrm{mmol} \mathrm{L}^{-1}$ 程度の金属の濃度でもケイ酸の錯形成が測定 可能であることが ESI-MS による測定の利点である.

ESI-MS は, プローブ先端から噴霧した試料溶液に高電 圧を印加するイオン化法である. ESI-MS の長所は,

1）溶液中の金属イオンの性質を反映した結果が得られる

2）複数の元素を同時に測定できる

3）試料をそのまま測定できる

4）正イオンと負イオンを同時に測定できる

5) $\mathrm{mmol} \mathrm{L}^{-1}$ 程度の試料を測定できる

などが挙げられる。この ESI-MS による測定は，金属のス ペシエーション ${ }^{12)}$ や溶液中の化学反応の解明 ${ }^{13)}$ にも用いら 
Table 1 Operating conditions of ESI-MS (LCMS2010A)

\begin{tabular}{cc}
\hline Sample volume & $5 \mu \mathrm{L}$ \\
Mobile phase & Purified water \\
Mass range & $m / z 0-500$ \\
Q-array RF lens & $150 \mathrm{~V}$ \\
Probe voltage & $4.5 \mathrm{kV}:-3.5 \mathrm{kV}$ \\
Nebulize gas flow-rate & $1.0 \mathrm{~L} \mathrm{~min}{ }^{-1}$ \\
CDL voltage & $20 \mathrm{~V}$ \\
CDL temperature & $250{ }^{\circ} \mathrm{C}$ \\
\hline
\end{tabular}

れる.しかし，イオンが気相中で化学反応を起こす「気相 反応」によって, 試料溶液中には存在しない化学種を生成 する場合 ${ }^{14)}$ がある. また, 気相反応によって生成した化学 種も溶液中に存在する化学種（溶存化学種）と区別なく検 出される. そのため, ESI-MS で検出された化学種について は,「気相反応によって生成した化学種か, もともと溶液に 存在する溶存化学種か」を検討する必要がある。言い換え れば, ESI-MS においては, 脱プロトン反応や, プロトン付 加などを含む気相反応が無視できない.これらの条件を検 討しながら，ケイ酸錯体と金属の安定性を調べることがで きれば，新たな知見が得られると考えた，本研究では， ESI-MS において検出されるケイ酸と各金属イオンの溶存 化学種の安定性を比較することにより, ケイ酸と金属イオ ンとの反応機構を考察した.

\section{2 実験}

\section{$2 \cdot 1$ 試 薬}

塩化カリウム $(\mathrm{KCl})$, 塩化カルシウム二水和物 $\left(\mathrm{CaCl}_{2}\right.$ • $\left.2 \mathrm{H}_{2} \mathrm{O}\right)$, 塩化ストロンチウム六水和物 $\left(\mathrm{SrCl}_{2} \cdot 6 \mathrm{H}_{2} \mathrm{O}\right)$, 塩 化亜鉛 $\left(\mathrm{ZnCl}_{2}\right)$ は関東化学製の特級を用いた. 塩化ナトリ ウム $(\mathrm{NaCl})$, 塩化セシウム $(\mathrm{CsCl})$, 塩化マグネシウム六 水和物 $\left(\mathrm{MgCl}_{2} \cdot 6 \mathrm{H}_{2} \mathrm{O}\right)$, 塩化バリウム二水和物 $\left(\mathrm{BaCl}_{2} \cdot\right.$ $\left.2 \mathrm{H}_{2} \mathrm{O}\right)$, 塩化マンガン (II) 四水和物 $\left(\mathrm{MnCl}_{2} \cdot 4 \mathrm{H}_{2} \mathrm{O}\right)$, 塩化 鉄(II) 四水和物 $\left(\mathrm{FeCl}_{2} \cdot 4 \mathrm{H}_{2} \mathrm{O}\right)$, 塩化コバルト (II) 六水和 物 $\left(\mathrm{CoCl}_{2} \cdot 6 \mathrm{H}_{2} \mathrm{O}\right)$, 塩化ニッケル (II) 六水和物 $\left(\mathrm{NiCl}_{2} \cdot\right.$ $\left.6 \mathrm{H}_{2} \mathrm{O}\right)$, 塩化銅 $(\mathrm{II})$ 二水和物 $\left(\mathrm{CuCl}_{2} \cdot 2 \mathrm{H}_{2} \mathrm{O}\right)$ は和光純薬工 業製の特級を用いた．塩化リチウム（LiCl）は関東化学製 の鹿特級, 塩化ルビジウム（RbCl）は関東化学製の純度 $95 \%$ 以上の試薬を用いた。 試料の調製及び希釈には, 比 抵抗 $18.2 \mathrm{M} \Omega$ 以上の超純水を用いた.

\section{$\mathbf{2} \cdot \mathbf{2}$ 装 置}

測定には, ESI-MS（SHIMADZU LCMS-2010A）を用い た.この装置は, インターフェースでの試料の噴霧と同時 に電圧が印加され，イオン化が行われる．試料は, 移動相 へ試料を導入し, それを ESI プローブに導く方法（フロー インジェクション法) を用いた. 試料との化学反応を避け
るため，移動相には超純水を用いた．装置条件を Table 1 に示す．実験 4 では curved desolvation line（CDL）の温 度, 実験 5 では ESI プローブの印加電圧を変化させた.

\section{$2 \cdot 3$ 操 作}

2.3・1 実験 1 ケイ酸試料の測定 ケイ酸標準試料 は, 一般的にはケイフッ化ナトリウム水溶液や石英をアル カリ融解した水ガラスが用いられる。しかし, ESI-MS の測 定においては, $\mathrm{Na}^{+}$などによるイオンサプレッションや水 ガラスから出るケイ酸溶液由来の金属イオンを検出してし まう可能性がある. そこで本研究では稲作用のケイ酸肥料 である Water Silica (富士シリシア製) から調製した溶液を 用いた. 具体的な操作としては, $40 \mathrm{~g}$ の Water Silica を $400 \mathrm{~g}$ の超純水に入れ $25{ }^{\circ} \mathrm{C}$ で 1 週間振とうし, 遠心分離を 行い, その上澄み溶液をケイ酸溶液 (約 $2 \mathrm{mmol} \mathrm{L}^{-1}$ ) とし て用いた。

$2 \cdot 3 \cdot 2$ 実験 $2 \mathrm{MCl}$ 溶液（ $\mathrm{MCl}_{2}$ 溶液）の測定 $\mathrm{MCl}$ 溶液または $\mathrm{MCl}_{2}$ 溶液 $(\mathrm{M}=\mathrm{Li}, \mathrm{Na}, \mathrm{K}, \mathrm{Rb}, \mathrm{Cs}, \mathrm{Mg}, \mathrm{Ca}$, $\mathrm{Sr}, \mathrm{Ba}, \mathrm{Mn}, \mathrm{Fe}, \mathrm{Co}, \mathrm{Ni}, \mathrm{Cu}, \mathrm{Zn})$ を $1 \mathrm{mM}$ になるよう それぞれ調製し，24 時間後，これらの試料を ESI-MS で測 定した.

$2 \cdot 3 \cdot 3$ 実験 3 ケイ酸+ $\mathrm{MCl}$ 溶液 $\left(\mathrm{MCl}_{2}\right)$ の測定 $1 \mathrm{mM}$ のケイ酸と $1 \mathrm{mM}$ の $\mathrm{MCl}$ たは $\mathrm{MCl}_{2}$ の溶液を ESI-MS で測定した.

2.3.4 実験 4 ESI-MS のイオン化条件変化（CDL温度） 本研究で用いた ESI-MS は，エレクトロスプレーで生成し た微小荷電粒子に含まれる溶媒成分を加熱によってさらに 取り除く機構（CDL）を持つ.この CDL の温度（CDL 温 度）は $300{ }^{\circ} \mathrm{C}$ 以下で自由に設定することができ, 加熱温度 を高くすることで, 気相中で不安定な化学種が減少し, そ れに伴い安定な化学種が増加することが期待できる．そこ で, CDL 温度を $200 \sim 300{ }^{\circ} \mathrm{C}$ の範囲で $25{ }^{\circ} \mathrm{C}$ ごとに, 実 験 3 で用いた溶液を測定した. CDL 温度以外の装置条件は Table 1 と同様に設定した.

2・3・5 実験 5 ESI-MS のイオン化条件変化（印加電圧） ESI のインターフェース部のプローブに印加する電圧 (probe voltage) を変化させることでも, ESI-MS のイオン 化の条件を変えられる，たとえば，負イオンモードでは， この電圧を下げる（絶対值を小さくする）ことによって放 電が抑えられ，安定なイオン化が行われる，すなわち，不 安定な化学種であっても安定な検出が達成されることが期 待できる. LCMS-2010A では，この電圧を正イオンモード で+5.0 kV まで, 負イオンモードでー $5.0 \mathrm{kV}$ まで設定する ことができる. そこで, 実験 3 で測定した溶液を正イオン モードでは+3.0〜+5.0 kV，負イオンモードでは-5.0〜 $-3.0 \mathrm{kV}$ の範囲で $0.5 \mathrm{kV}$ ごとに測定した. プローブの印加 電圧以外の装置条件は Table 1 と同様に設定した. 
a)

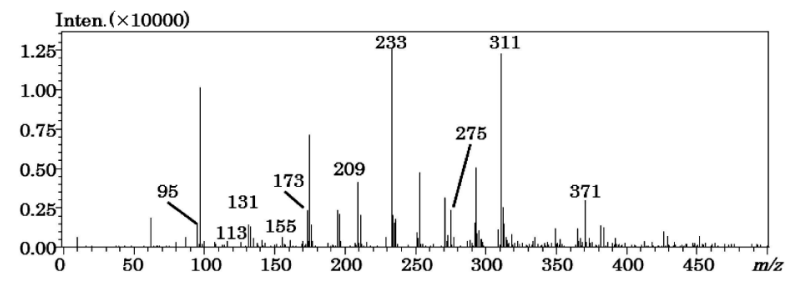

b)

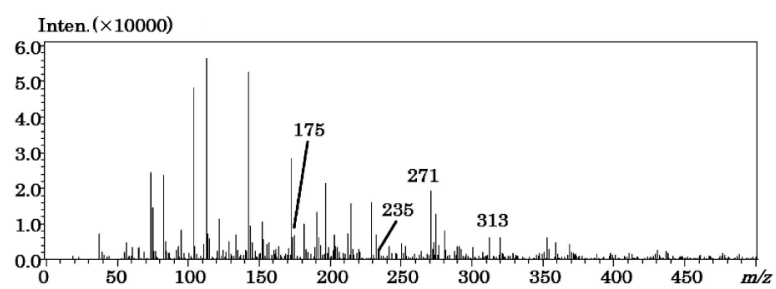

Fig. 1 ESI-MS spectra of a $1.0 \mathrm{mM}$ silicic acid solution a) Negative ion mode; b) positive ion mode.

\section{3 結果と考察}

\section{$3 \cdot 1$ 実験 1 ケイ酸溶液の測定}

$1 \mathrm{mM}$ ケイ酸溶液を測定したマススペクトルを Fig. 1 に, 同定した化学種を Table 2 に示す. ケイ酸の化学種は $\mathrm{m} / \mathrm{z}$ 0〜500 の負イオンモードにおいて $1 \sim 5$ 量体が, 正イオン モードに扔いて 2〜5量体が検出された，water silicaを試 料として用いた測定においても，ほかのシリカゲルを水酸 化カルシウム, 水酸化ナトリウムで溶かした ESI-MS の報 告 ${ }^{15}{ }^{16)}$ や海水中のケイ酸を FAB-MS で測定した研究 ${ }^{17)}$ と同 様の化学種が検出された，溶液中のケイ酸の脱水縮合，ま たは脱溶媒の作用による $m / z 173,155,137$ の 2 量体の化 学種が観察された。一般的に負イオンモードに扔いては, キャピラリー先端に発生するコロナ放電プラズマの影響に より, 安定なエレクトロスプレーが得にくい(18). しかし, シリカは負コロイドで存在するので, ケイ酸イオンは負イ オンで安定であり，負イオンモードにおいてはESI-MSに おいて溶液中の溶存状態を反映した化学種が観察された。 一方で，正イオンモードでは，ESIによる強制的なイオン 化を受けているため, 安定な負イオンにプロトンが付加し た化学種が検出された.

\section{$3 \cdot 2$ 実験 $2 \mathrm{MCl}$ 溶液 $\left(\mathrm{MCl}_{2}\right.$ 溶液 $)$ の測定}

ESI-MS を用いて $1 \mathrm{mM} の \mathrm{MCl}$ 及び $\mathrm{MCl}_{2}$ を測定したマス スペクトルを Fig. 2 に示す. 検出された化学種は, 1 族元 素, 2 族元素, 遷移金属元素ごとにそれぞれ特徴があり，こ の差は元素の性質に基づいた安定性を反映していると考え た． 1 族及び 2 族元素，遷移金属元素それぞれ同定された 化学種を Table 3 及び Table 4 に示した.
Table 2 Identified species in a $1 \mathrm{mM}$ silicic acid solution

a) Negative ion mode

\begin{tabular}{lrll}
\hline & $m / z$ & \multicolumn{1}{c}{ species } \\
\hline monomer & 95 & {$\left[\mathrm{Si}_{2}(\mathrm{OH})_{3} \mathrm{O}\right]^{-}$} \\
& 113 & {$\left[\mathrm{Si}(\mathrm{OH})_{3} \mathrm{O}\left(\mathrm{H}_{2} \mathrm{O}\right)\right]^{-}$} \\
& 131 & {$\left[\mathrm{Si}(\mathrm{OH})_{3} \mathrm{O}\left(\mathrm{H}_{2} \mathrm{O}\right)_{2}\right]^{-}$} \\
dimer & 137 & {$\left[\mathrm{Si}_{2}(\mathrm{OH})_{4}\right]_{4}$} \\
& 155 & {$\left[\mathrm{Si}_{2}(\mathrm{OH})_{3} \mathrm{O}_{3}\right]^{-}$} \\
& 173 & {$\left[\mathrm{Si}_{2}(\mathrm{OH})_{5} \mathrm{O}_{2}\right]^{-}$} \\
& 191 & {$\left[\mathrm{Si}_{2}(\mathrm{OH})_{5} \mathrm{O}_{2}\left(\mathrm{H}_{2} \mathrm{O}\right)\right]^{-}$} \\
& 209 & {$\left[\mathrm{Si}_{2}(\mathrm{OH})_{5} \mathrm{O}_{2}\left(\mathrm{H}_{2} \mathrm{O}\right)_{2}\right]^{-}$} \\
trimer & 215 & {$\left[\mathrm{Si}_{3}(\mathrm{OH})_{3} \mathrm{O}_{5}\right]^{-}$} \\
& 233 & {$\left[\mathrm{Si}_{3}(\mathrm{OH})_{5} \mathrm{O}_{4}\right]^{-}$} \\
& 251 & {$\left[\mathrm{Si}_{3}(\mathrm{OH})_{7} \mathrm{O}_{3}\right]^{-}, \quad\left[\mathrm{Si}_{3}(\mathrm{OH})_{5} \mathrm{O}_{4}\left(\mathrm{H}_{2} \mathrm{O}\right)\right]^{-}$} \\
& 287 & {$\left[\mathrm{Si}_{3}(\mathrm{OH})_{7} \mathrm{O}_{3}\left(\mathrm{H}_{2} \mathrm{O}\right)_{2}\right]^{-}$} \\
tetramer & 275 & {$\left[\mathrm{Si}_{4}(\mathrm{OH})_{3} \mathrm{O}_{7}\right]^{-}$} \\
& 293 & {$\left[\mathrm{Si}_{4}(\mathrm{OH})_{5} \mathrm{O}_{6}\right]^{-}$} \\
& 311 & {$\left[\mathrm{Si}_{4}(\mathrm{OH})_{7} \mathrm{O}_{5}\right]^{-}, \quad\left[\mathrm{Si}_{4}(\mathrm{OH})_{5} \mathrm{O}_{6}\left(\mathrm{H}_{2} \mathrm{O}\right)\right]^{-}$} \\
& & \\
pentamer & 371 & {$\left[\mathrm{Si}_{5}(\mathrm{OH})_{7} \mathrm{O}_{7}\right]^{-}$} \\
\hline
\end{tabular}

b) Positive ion mode

\begin{tabular}{lll}
\hline & $m / z$ & \multicolumn{1}{c}{ species } \\
\hline dimer & 175 & {$\left[\mathrm{Si}_{2}(\mathrm{OH})_{5} \mathrm{O}_{2}{ }^{-}+2 \mathrm{H}^{+}\right]^{+}$} \\
trimer & 235 & {$\left[\mathrm{Si}_{3}(\mathrm{OH})_{5} \mathrm{O}_{4}{ }^{-}+2 \mathrm{H}^{+}\right]^{+}$} \\
& 271 & {$\left[\mathrm{Si}_{3}(\mathrm{OH})_{7} \mathrm{O}_{3}\left(\mathrm{H}_{2} \mathrm{O}\right)^{-}+2 \mathrm{H}^{+}\right]^{+}$} \\
\multirow{2}{*}{ tetramer } & 277 & {$\left[\mathrm{Si}_{4}(\mathrm{OH})_{3} \mathrm{O}_{7}{ }^{-}+2 \mathrm{H}^{+}\right]^{+}$} \\
& 313 & {$\left[\mathrm{Si}_{4}(\mathrm{OH})_{7} \mathrm{O}_{5}{ }^{-}+2 \mathrm{H}^{+}\right]^{+}$} \\
pentamer & 373 & {$\left[\mathrm{Si}_{5}(\mathrm{OH})_{7} \mathrm{O}_{7}{ }^{-}+2 \mathrm{H}^{+}\right]^{+}$} \\
\hline
\end{tabular}

$3 \cdot 2 \cdot 1 \quad 1$ 族元素 1 族元素は正イオンモードの Liを除 いて，規則的なピークが検出された．正イオンモードの Li のマススペクトルでは, Li 由来のピークは同定できなかっ た. 負イオンモードにおいては, $\mathrm{Cl}^{-}(m / z 35)$ から $\mathrm{MCl}$ ごとに, 正イオンモードにおいては, $\mathrm{M}^{+}$から付加した $\mathrm{MCl}$ ごとに規則的に化学種が検出された.

$3 \cdot 2 \cdot 22$ 族元素と 2 価の遷移金属元素の比較 2 族元 素, 遷移金属元素で検出された化学種は大きく分けて (1) $[\mathrm{M}]^{+}$, (2) $\left[\mathrm{M}(\mathrm{OH})\left(\mathrm{H}_{2} \mathrm{O}\right)_{n}\right]^{+}$, (3) $\left[\mathrm{M}\left(\mathrm{H}_{2} \mathrm{O}\right)_{n}\right]^{2+}$ 及 び (4) $\left[\mathrm{M}_{2}(\mathrm{OH})_{3}\left(\mathrm{H}_{2} \mathrm{O}\right)_{n}\right]^{+}$であった. これを Fig. 3 に示す.

(2) $\left[\mathrm{M}(\mathrm{OH})\left(\mathrm{H}_{2} \mathrm{O}\right)_{n}\right]^{+}$及び (4) $\left[\mathrm{M}_{2}(\mathrm{OH})_{3}\left(\mathrm{H}_{2} \mathrm{O}\right)_{n^{\prime}}\right]^{+}$につい ては, $\mathrm{Cl}^{-}$及び $\left[\mathrm{H}_{2} \mathrm{O}(\mathrm{OH})\right]^{-}$が $m / z 35$ で同じことから, そ れぞれ (2) $\left[\mathrm{MCl}\left(\mathrm{H}_{2} \mathrm{O}\right)_{m}\right]^{+}$及び (4) $\left[\mathrm{M}_{2} \mathrm{Cl}_{3}\left(\mathrm{H}_{2} \mathrm{O}\right)_{m^{\prime}}\right]^{+}$である 可能性がある. 例えば $\mathrm{Co}$ の場合, $\left[\mathrm{Co}(\mathrm{OH})\left(\mathrm{H}_{2} \mathrm{O}\right)_{3}\right]^{+}$及び $\left[\mathrm{CoCl}\left(\mathrm{H}_{2} \mathrm{O}\right)_{2}\right]^{+}$はどちらも $m / z 130$ で検出される. 本研究 ではイオン強度を定量的に扱っておらず，化学種の有無の 判断のみのため, $\mathrm{Cl}$ の同位体比 ${ }^{35} \mathrm{Cl}:{ }^{37} \mathrm{Cl}=3: 1$ から検出 されたマススペクトルの分布を計算值の分布と比較して化 学種の有無を判断した. 
2 族元素, 遷移金属元素とも溶液中では金属イオンその ものは 2 価で安定なため, (1) $[\mathrm{M}]^{+}$の化学種は溶液中に存 在しえない. したがって (1) の化学種は ESI-MS のイオン化 による還元を受けて生成した化学種であると考えられる. すなわち,

a)

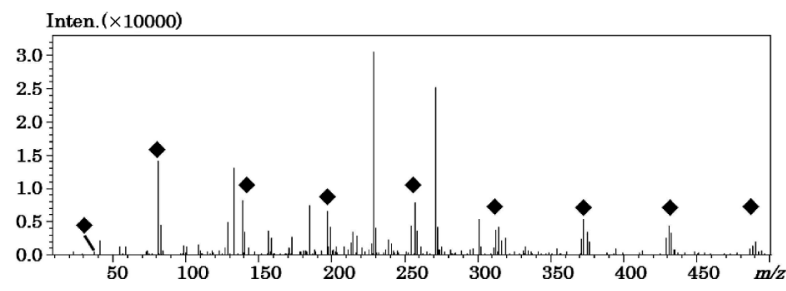

b)

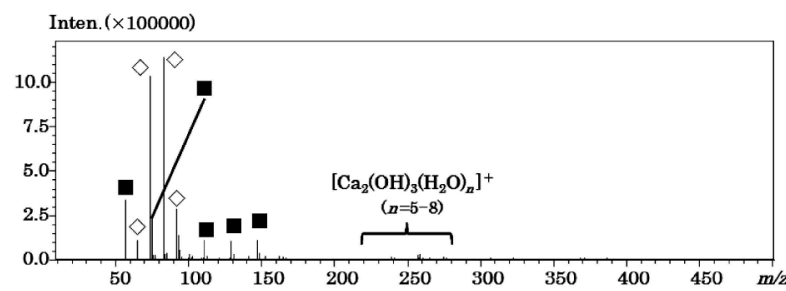

c)

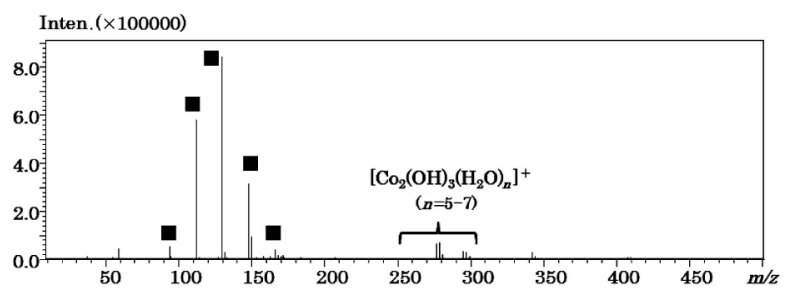

Fig. 2 ESI-MS spectra of a $1.0 \mathrm{mM} \mathrm{MCl}$ or $\mathrm{MCl}_{2}$ solution in positive ion mode

a) $\mathrm{M}=\mathrm{Na}$; b) $\mathrm{M}=\mathrm{Ca}$; c) $\mathrm{M}=\mathrm{Co}$.

$\left[\mathrm{M}_{n} \mathrm{Cl}_{n-1}\right]^{+}$

$\left[\mathrm{M}(\mathrm{OH})\left(\mathrm{H}_{2} \mathrm{O}\right)_{n}\right]^{+} ; \diamond,\left[\mathrm{M}\left(\mathrm{H}_{2} \mathrm{O}\right)_{n}\right]^{2+}$.
$\mathrm{M}^{2+}+\mathrm{e}^{-} \rightarrow \mathrm{M}^{+}$

という反応が生じている.この化学種が検出された元素 は，遷移金属元素と $\mathrm{Sr}$ であったが, $[\mathrm{Sr}]^{+}(m / z 88)$ につ いては, $\left[{ }^{88} \mathrm{Sr}\left(\mathrm{H}_{2} \mathrm{O}\right)_{5}\right]^{2+}(m / z 89)$ の同位体の化学種 $\left[{ }^{86} \mathrm{Sr}\left(\mathrm{H}_{2} \mathrm{O}\right)_{5}\right]^{2+}(m / z 88)$ であるとも考えられる.したがっ て，遷移金属元素のみが ESI-MS による還元を受けると考 えられる.

(2) $\left[\mathrm{M}(\mathrm{OH})\left(\mathrm{H}_{2} \mathrm{O}\right)_{n}\right]^{+}$は以下の化学式の様に (3) $\left[\mathrm{M}\left(\mathrm{H}_{2} \mathrm{O}\right)_{n}\right]^{2+}$ が加水分解して生成した化学種である.

$$
\left[\mathrm{M}\left(\mathrm{H}_{2} \mathrm{O}\right)_{n}\right]^{2+}+\mathrm{H}_{2} \mathrm{O} \rightarrow\left[\mathrm{M}(\mathrm{OH})\left(\mathrm{H}_{2} \mathrm{O}\right)_{n}\right]^{+}+\mathrm{H}^{+}
$$

遷移金属元素は $\mathrm{pH} 5.0$ 付近では, 加水分解を生じており,

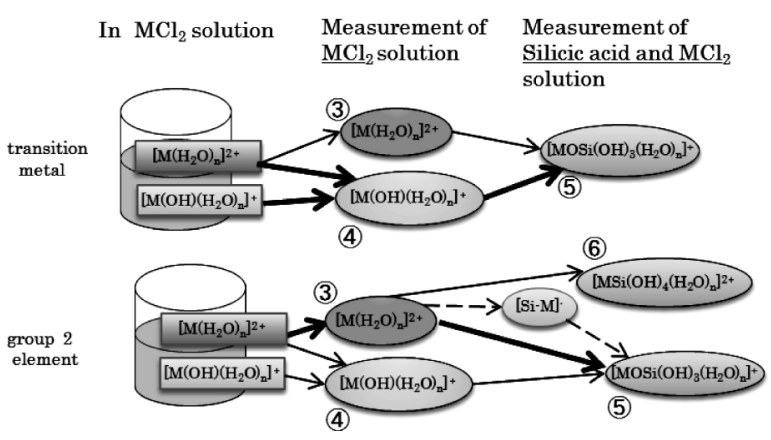

Fig. 3 Schematic view of the estimated reactions of ESI-MS

Bold arrow lines show main reactions of a group-2 element $(\mathrm{Mg}, \mathrm{Ca}, \mathrm{Sr}, \mathrm{Ba})$ and transition metals $(\mathrm{Mn}$, $\mathrm{Fe}, \mathrm{Co}, \mathrm{Ni}, \mathrm{Cu}, \mathrm{Zn}$ ) with silicic acid. Dotted lines show the reactions of $\mathrm{Ca}^{2+}$ besides the reaction presented by arrow lines. $[\mathrm{Si}-\mathrm{M}]^{-}$means silica and calcium complexes.

Table 3 Identified species in a $1 \mathrm{mM} \mathrm{MCl}(\mathrm{M}=\mathrm{Li}, \mathrm{Na}, \mathrm{K}, \mathrm{Cs}, \mathrm{Rb})$ solution a) Negative ion mode

\begin{tabular}{clll}
\hline Metal & \multicolumn{1}{c}{ species } & \multicolumn{1}{c}{$m / z$} & \multicolumn{1}{c}{$m / z$} \\
\hline $\mathrm{Li}$ & {$\left[\mathrm{M}_{n} \mathrm{Cl}_{n+1}\right]^{-}$} & $(n=0-11)$ & $35,77,119,161,203,245,287,329,371,413,455,497$ \\
$\mathrm{Na}$ & {$\left[\mathrm{M}_{n} \mathrm{Cl}_{n+1}\right]^{-}$} & $(n=0-8)$ & $35,93,151,209,267,325,383,441,499$ \\
$\mathrm{~K}$ & {$\left[\mathrm{M}_{n} \mathrm{Cl}_{n+1}\right]^{-}$} & $(n=0-6)$ & $35,109,183,257,331,405,479$ \\
$\mathrm{Rb}$ & {$\left[\mathrm{M}_{n} \mathrm{Cl}_{n+1}\right]^{-}$} & $(n=0-3)$ & $35,155,275,395$ \\
$\mathrm{Cs}$ & {$\left[\mathrm{M}_{n} \mathrm{Cl}_{n+1}\right]^{-}$} & $(n=0-2)$ & $35, \underline{203}, 371$ \\
\hline
\end{tabular}

b) Positive ion mode

\begin{tabular}{|c|c|c|c|}
\hline Metal & species & & $m / z$ \\
\hline $\mathrm{Li}$ & not identification & & - \\
\hline $\mathrm{Na}$ & {$\left[\mathrm{M}_{n} \mathrm{Cl}_{n-1}\right]^{+}$} & $(n=1-9)$ & $23,81,139,197,255,313,371,429,487$ \\
\hline $\mathrm{K}$ & {$\left[\mathrm{M}_{n} \mathrm{Cl}_{n-1}\right]^{+}$} & $(n=1-7)$ & $\underline{39}, 113,187,261,335,409,483$ \\
\hline $\mathrm{Rb}$ & {$\left[\mathrm{M}_{n} \mathrm{Cl}_{n-1}\right]^{+}$} & $(n=1-4)$ & $\overline{85}, 205,325,445$ \\
\hline Cs & {$\left[\mathrm{M}_{n} \mathrm{Cl}_{n-1}\right]^{+}$} & $(n=1-3)$ & $\overline{133}, 301,469$ \\
\hline
\end{tabular}


Table 4 Identified species in a $1 \mathrm{mM} \mathrm{MCl}$ solution in the positive ion mode a) $\mathrm{M}=\mathrm{Mg}, \mathrm{Ca}, \mathrm{Sr}, \mathrm{Ba}$

\begin{tabular}{|c|c|c|c|}
\hline Metal & species & & $m / z$ \\
\hline $\mathrm{Mg}$ & $\begin{array}{l}{[\mathrm{M}]^{+}} \\
{\left[\mathrm{M}(\mathrm{OH})\left(\mathrm{H}_{2} \mathrm{O}\right)_{n}\right]^{+}} \\
{\left[\mathrm{M}\left(\mathrm{H}_{2} \mathrm{O}\right)_{n}\right]^{2+}} \\
{\left[\mathrm{M}_{2}(\mathrm{OH})_{3}\left(\mathrm{H}_{2} \mathrm{O}\right)_{n}\right]^{+}}\end{array}$ & $\begin{array}{l}(n=0-6) \\
(n=5-11) \\
(n=5-7)\end{array}$ & $\begin{array}{l}-- \\
41,59,77,95,113,131,149 \\
57,66,75,84,93,102,111 \\
189,207,225\end{array}$ \\
\hline $\mathrm{Ca}$ & $\begin{array}{l}{[\mathrm{M}]^{+}} \\
{\left[\mathrm{M}(\mathrm{OH})\left(\mathrm{H}_{2} \mathrm{O}\right)_{n}\right]^{+}} \\
{\left[\mathrm{M}\left(\mathrm{H}_{2} \mathrm{O}\right)_{n}\right]^{2+}} \\
{\left[\mathrm{M}_{2}(\mathrm{OH})_{3}\left(\mathrm{H}_{2} \mathrm{O}\right)_{n}\right]^{+}}\end{array}$ & $\begin{array}{l}(n=0-6) \\
(n=4-10) \\
(n=5-8)\end{array}$ & \begin{tabular}{l}
\multicolumn{1}{c}{-} \\
$57,75,93,111,129,147,165$ \\
$56,65,74, \underline{83}, 92,101,110$ \\
$221,239,257,275$
\end{tabular} \\
\hline $\mathrm{Sr}$ & $\begin{array}{l}{[\mathrm{M}]^{+}} \\
{\left[\mathrm{M}(\mathrm{OH})\left(\mathrm{H}_{2} \mathrm{O}\right)_{n}\right]^{+}} \\
{\left[\mathrm{M}\left(\mathrm{H}_{2} \mathrm{O}\right)_{n}\right]^{2+}} \\
{\left[\mathrm{M}_{2}(\mathrm{OH})_{3}\left(\mathrm{H}_{2} \mathrm{O}\right)_{n}\right]^{+}}\end{array}$ & $\begin{array}{l}(n=0-6) \\
(n=0-10) \\
(n=7)\end{array}$ & $\begin{array}{l}88 \\
105,123,141,159,177,195,213 \\
44,53,62,71,80,89, \underline{98}, 107,116,125,134 \\
353\end{array}$ \\
\hline $\mathrm{Ba}$ & $\begin{array}{l}{[\mathrm{M}]^{+}} \\
{\left[\mathrm{M}(\mathrm{OH})\left(\mathrm{H}_{2} \mathrm{O}\right)_{n}\right]^{+}} \\
{\left[\mathrm{M}\left(\mathrm{H}_{2} \mathrm{O}\right)_{n}\right]^{2+}} \\
{\left[\mathrm{M}_{2}(\mathrm{OH})_{3}\left(\mathrm{H}_{2} \mathrm{O}\right)_{n}\right]^{+}}\end{array}$ & $\begin{array}{l}(n=0-5) \\
(n=0-9) \\
(n=5,6)\end{array}$ & $\begin{array}{l}-- \\
155,173,191,209,227,245 \\
69,78,87,96,105,114, \underline{123}, 132,141,150 \\
417,435\end{array}$ \\
\hline
\end{tabular}

b) $\mathrm{M}=\mathrm{Mn}, \mathrm{Fe}, \mathrm{Co}, \mathrm{Ni}, \mathrm{Cu}, \mathrm{Zn}$

\begin{tabular}{|c|c|c|c|}
\hline Metal & species & & $m / z$ \\
\hline Mn & $\begin{array}{l}{[\mathrm{M}]^{+}} \\
{\left[\mathrm{M}(\mathrm{OH})\left(\mathrm{H}_{2} \mathrm{O}\right)_{n}\right]^{+}} \\
{\left[\mathrm{M}\left(\mathrm{H}_{2} \mathrm{O}\right)_{n}\right]^{2+}} \\
{\left[\mathrm{M}_{2}(\mathrm{OH})_{3}\left(\mathrm{H}_{2} \mathrm{O}\right)_{n}\right]^{+}}\end{array}$ & $\begin{array}{l}(n=0-6) \\
(n=6,8) \\
(n=6,7)\end{array}$ & $\begin{array}{l}55 \\
72,90,108,126,144,162,180 \\
81.5,99.5 \\
269,287\end{array}$ \\
\hline $\mathrm{Fe}$ & $\begin{array}{l}{[\mathrm{M}]^{+}} \\
{\left[\mathrm{M}(\mathrm{OH})\left(\mathrm{H}_{2} \mathrm{O}\right)_{n}\right]^{+}} \\
{\left[\mathrm{M}\left(\mathrm{H}_{2} \mathrm{O}\right)_{n}\right]^{2+}} \\
{\left[\mathrm{M}_{2}(\mathrm{OH})_{3}\left(\mathrm{H}_{2} \mathrm{O}\right)_{n}\right]^{+}}\end{array}$ & $\begin{array}{l}(n=0-6) \\
(n=1,3,5,7,9) \\
(n=5-7)\end{array}$ & $\begin{array}{l}56 \\
73,91,109,127,145,163,181 \\
37,55,73,91,109 \\
253,271,289\end{array}$ \\
\hline Co & $\begin{array}{l}{[\mathrm{M}]^{+}} \\
{\left[\mathrm{M}(\mathrm{OH})\left(\mathrm{H}_{2} \mathrm{O}\right)_{n}\right]^{+}} \\
{\left[\mathrm{M}\left(\mathrm{H}_{2} \mathrm{O}\right)_{n}\right]^{2+}} \\
{\left[\mathrm{M}_{2}(\mathrm{OH})_{3}\left(\mathrm{H}_{2} \mathrm{O}\right)_{n}\right]^{+}}\end{array}$ & $\begin{array}{l}(n=0-6) \\
(n=5-7)\end{array}$ & $\begin{array}{l}59 \\
76,94,112, \underline{130}, 148,166,184 \\
\quad- \\
259,277,295\end{array}$ \\
\hline $\mathrm{Ni}$ & $\begin{array}{l}{[\mathrm{M}]^{+}} \\
{\left[\mathrm{M}(\mathrm{OH})\left(\mathrm{H}_{2} \mathrm{O}\right)_{n}\right]^{+}} \\
{\left[\mathrm{M}\left(\mathrm{H}_{2} \mathrm{O}\right)_{n}\right]^{2+}} \\
{\left[\mathrm{M}_{2}(\mathrm{OH})_{3}\left(\mathrm{H}_{2} \mathrm{O}\right)_{n}\right]^{+}}\end{array}$ & $\begin{array}{l}(n=0-6) \\
(n=6-9) \\
(n=5-7)\end{array}$ & $\begin{array}{l}58 \\
75,93,111,129,147,165,183 \\
83,92,101,110 \\
257,275,293\end{array}$ \\
\hline $\mathrm{Cu}$ & $\begin{array}{l}{[\mathrm{M}]^{+}} \\
{\left[\mathrm{M}(\mathrm{OH})\left(\mathrm{H}_{2} \mathrm{O}\right)_{n}\right]^{+}} \\
{\left[\mathrm{M}\left(\mathrm{H}_{2} \mathrm{O}\right)_{n}\right]^{2+}} \\
{\left[\mathrm{M}_{2}(\mathrm{OH})_{3}\left(\mathrm{H}_{2} \mathrm{O}\right)_{n}\right]^{+}}\end{array}$ & $\begin{array}{l}(n=1-7) \\
(n=5,6)\end{array}$ & $\begin{array}{l}63 \\
98, \underline{116}, 134,152,170,188,206 \\
267, \overline{285}\end{array}$ \\
\hline $\mathrm{Zn}$ & $\begin{array}{l}{[\mathrm{M}]^{+}} \\
{\left[\mathrm{M}(\mathrm{OH})\left(\mathrm{H}_{2} \mathrm{O}\right)_{n}\right]^{+}} \\
{\left[\mathrm{M}\left(\mathrm{H}_{2} \mathrm{O}\right)_{n}\right]^{2+}} \\
{\left[\mathrm{M}_{2}(\mathrm{OH})_{3}\left(\mathrm{H}_{2} \mathrm{O}\right)_{n}\right]^{+}}\end{array}$ & $\begin{array}{l}(n=0-7) \\
(n=3,4) \\
(n=5,7)\end{array}$ & $\begin{array}{l}64 \\
81,99,117, \underline{135}, 153,171,189,207 \\
59,68 \\
269,305\end{array}$ \\
\hline
\end{tabular}

: main species, $\square$ : overlapping species.

ごく一部が (3) $\left[\mathrm{M}\left(\mathrm{H}_{2} \mathrm{O}\right)_{n}\right]^{2+}$ であり，主に (2) $[\mathrm{M}(\mathrm{OH})$ $\left.\left(\mathrm{H}_{2} \mathrm{O}\right)_{n}\right]^{+}$として検出された.一方, 2 族元素は (2) $[\mathrm{M}(\mathrm{OH})$ $\left.\left(\mathrm{H}_{2} \mathrm{O}\right)_{n}\right]^{+}$も検出したが, 主に (3) $\left[\mathrm{M}\left(\mathrm{H}_{2} \mathrm{O}\right)_{n}\right]^{2+}$ が検出され た. このことから, 遷移金属元素は加水分解して検出され ていることが観察でき, 元素の加水分解定数 ${ }^{19)}$ の傾向と一 致する.つまり， 2 族元素でも (2) $\left[\mathrm{M}(\mathrm{OH})\left(\mathrm{H}_{2} \mathrm{O}\right)_{n}\right]^{+}$で検出 されているが, ほとんどは溶液中の (3) $\left[\mathrm{M}\left(\mathrm{H}_{2} \mathrm{O}\right)_{n}\right]^{2+}$ を保
持して検出された.

$3 \cdot 3$ 実験 3 ケイ酸+ $\mathrm{MCl}$ 溶液（ $\mathrm{MCl}_{2}$ 溶液）の測定

$1 \mathrm{mM}$ のケイ酸溶液と $1 \mathrm{mM}$ の $\mathrm{MCl}$ または $\mathrm{MCl}_{2}$ を混合 した溶液を測定したマススペクトルを Fig. 4 に，新たに検 出した化学種を Table 5 に示す.

$3 \cdot 3 \cdot 1$ 正イオンモード 2 族元素及び遷移金属元素 
a-1)

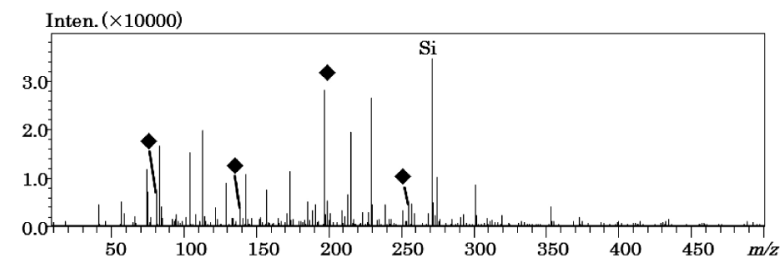

a-2)

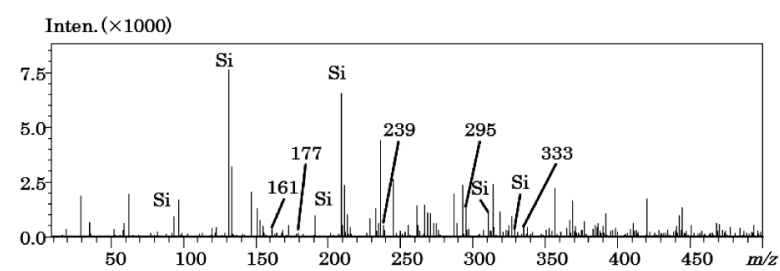

b-1)

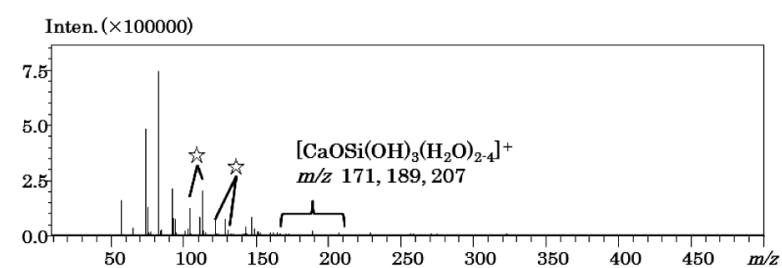

b-2)

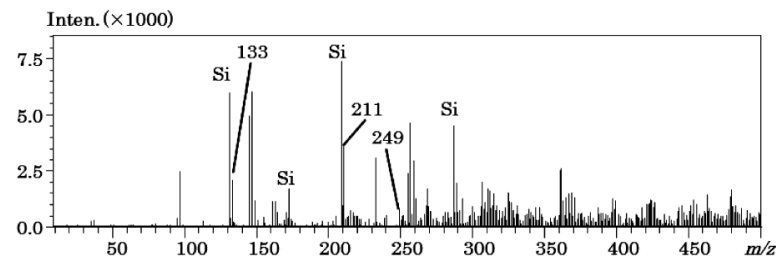

Fig. 4 ESI-MS spectra of a $1.0 \mathrm{mM}$ silicic acid and $\mathrm{MCl}$ or $\mathrm{MCl}_{2}$ solution

a-1) $\mathrm{NaCl}$ in positive ion mode; a-2) $\mathrm{NaCl}$ in negative ion mode; b-1) $\mathrm{CaCl}_{2}$ in positive ion mode; b-2) $\mathrm{CaCl}_{2}$ in negative ion mode. Marks of $\mathrm{Si}$ mean only silicic acid species and $\hat{z}$ is $\left[\mathrm{CaSi}(\mathrm{OH})_{4}\left(\mathrm{H}_{2} \mathrm{O}\right)_{n}\right]^{2+}$.

は正イオンモードにおいて, 実験 2 で検出した化学種に加 え, Fig. 3 に示したようにケイ酸と錯形成した化学種 (5) $\left[\mathrm{MOSi}(\mathrm{OH})_{3}\left(\mathrm{H}_{2} \mathrm{O}\right)_{n}\right]^{+}$, (6) $\left[\mathrm{MSi}(\mathrm{OH})_{4}\left(\mathrm{H}_{2} \mathrm{O}\right)_{n}\right]^{2+}$ が検出 された. 2 族元素は, (5) $\left[\mathrm{MOSi}(\mathrm{OH})_{3}\left(\mathrm{H}_{2} \mathrm{O}\right)_{n}\right]^{+}$及び (6) $\left[\mathrm{MSi}(\mathrm{OH})_{4}\left(\mathrm{H}_{2} \mathrm{O}\right)_{n}\right]^{2+}$ が高いイオン強度で検出されたが, 遷移金属元素では (6) $\left[\mathrm{MSi}(\mathrm{OH})_{4}\left(\mathrm{H}_{2} \mathrm{O}\right)_{n}\right]^{2+}$ はほとんど検 出されなかった。これは，遷移金属のイオン化の際に，(6) $\left[\mathrm{MSi}(\mathrm{OH})_{4}\left(\mathrm{H}_{2} \mathrm{O}\right)_{n}\right]^{2+}$ を生成する元の化学種が存在してい なかったためと考えた.つまり, (6) $\left[\mathrm{MSi}(\mathrm{OH})_{4}\left(\mathrm{H}_{2} \mathrm{O}\right)_{n}\right]^{2+}$ は

$$
\left[\mathrm{M}\left(\mathrm{H}_{2} \mathrm{O}\right)_{n}\right]^{2+}+\mathrm{Si}(\mathrm{OH})_{4} \rightarrow\left[\mathrm{MSi}(\mathrm{OH})_{4}\left(\mathrm{H}_{2} \mathrm{O}\right)_{n}\right]^{2+}
$$

または，

$$
\begin{aligned}
& {\left[\mathrm{M}\left(\mathrm{H}_{2} \mathrm{O}\right)_{n}\right]^{2+}+\left[\mathrm{SiO}(\mathrm{OH})_{3}\right]^{-}+\mathrm{H}^{+} } \\
& \rightarrow\left[\mathrm{MSi}(\mathrm{OH})_{4}\left(\mathrm{H}_{2} \mathrm{O}\right)_{n}\right]^{2+}
\end{aligned}
$$

という反応を経て形成しており，実験 2 から，遷移金属元 素では (3) $\left[\mathrm{M}\left(\mathrm{H}_{2} \mathrm{O}\right)_{n}\right]^{2+}$ がほとんど存在しないと分かった. そのため, 実験 3 において (6) $\left[\mathrm{MSi}(\mathrm{OH})_{4}\left(\mathrm{H}_{2} \mathrm{O}\right)_{n}\right]^{2+}$ もまた 生成しなかったと考えられる. 2 族元素で周期表の下の元 素になるほど, (3) $\left[\mathrm{M}\left(\mathrm{H}_{2} \mathrm{O}\right)_{n}\right]^{2+}$ の水和数の小さい方が主た るピークになり, かつ, (6) $\left[\mathrm{MSi}(\mathrm{OH})_{4}\left(\mathrm{H}_{2} \mathrm{O}\right)_{n}\right]^{2+}$ の水和数 の範囲が小さい方になったことからも示唆される。 これは イオンの大きさを反映しており，イオンが大きくなるほど $\mathrm{M}^{2+}$ の表面電荷密度が小さくなるため, 水分子を配位しに くくなることで説明できる

2 族元素間でも化学種を形成する安定性の差が観察され た. $\mathrm{Ba}^{2+}$ は (5) $\left[\operatorname{MOSi}(\mathrm{OH})_{3}\left(\mathrm{H}_{2} \mathrm{O}\right)_{n}\right]^{+}$は $n=3$ のみで, 一方 (6) $\left[\mathrm{MSi}(\mathrm{OH})_{4}\left(\mathrm{H}_{2} \mathrm{O}\right)_{n}\right]^{2+}$ は 2 族元素の中では $\mathrm{Ba}^{2+}$ だけが $n=2 \sim 8$ と幅広い水和数で検出された. このことから, $\mathrm{Ba}$ のみほかの 2 族元素と比較して (5) $\left[\mathrm{MOSi}(\mathrm{OH})_{3}\left(\mathrm{H}_{2} \mathrm{O}\right)_{n}\right]^{+}$ よりも (6) $\left[\mathrm{MSi}(\mathrm{OH})_{4}\left(\mathrm{H}_{2} \mathrm{O}\right)_{n}\right]^{2+}$ を形成しやすいと考えら れる.このことから, $\mathrm{Ba}^{2+}$ は $\left[\mathrm{Ba}\left(\mathrm{H}_{2} \mathrm{O}\right)_{n}\right]^{2+}$ の生成がほかの 2 族元素に比べ高い割合で生じていることも分かる.

3.3.2 負イオンモード 負イオンモードに扔いて, 実験で用いた金属の中では $\mathrm{Ca}^{2+}$ と $\mathrm{Na}^{+}$のみでケイ酸と錯 形成した化学種が観察された．負イオンモードで同定され たケイ酸と金属の錯形成した化学種を Table 6 に，ケイ酸 と $\mathrm{Ca}^{2+}$ 及びケイ酸と $\mathrm{Na}^{+}$のマススペクトルを Fig. 3 に示 す. $\mathrm{Ca}^{2+}$ 及び $\mathrm{Na}^{+}$とケイ酸の錯体については FAB-MS を用 いた測定においても検出されており，溶液中に存在する化 学種が ESI-MS のイオン化の過程を経ても検出されたと考 えられる. $\mathrm{Ca}^{2+}$ と $\mathrm{Na}^{+}$の場合のみで検出された理由を $3 \cdot 4$ で考察する.

\section{$3 \cdot 4$ ケイ酸と金属の化学種の反応機構}

実験 1 3 3 り，2 族元素イオン及び遷移金属元素イオ ンの ESI-MS における化学種の検出機構を推測した. その 概要図をまとめて Fig. 3 に示す. ESI-MS においても, ケイ 酸そのものは主として負イオンで検出された．また， $\mathrm{MCl}_{2}$ 溶液を測定した際，2 族元素よりも遷移金属元素の方が, 加水分解が進んでおり, 金属の 2 価の化学種 (3) $\left[\mathrm{M}\left(\mathrm{H}_{2} \mathrm{O}\right)_{n}\right]^{2+}$ が存在しないため, ケイ酸を含めた溶液の測 定において 2 価の化学種由来のケイ酸との錯体 (6) $\left[\mathrm{MSi}(\mathrm{OH})_{4}\left(\mathrm{H}_{2} \mathrm{O}\right)_{n}\right]^{2+}$ を形成しなかった。 また, 2 族元素間 においても，ケイ酸との錯形成のしやすさが観察された. $\mathrm{Ba}^{2+}$ は (5) $\left[\mathrm{MOSi}(\mathrm{OH})_{3}\left(\mathrm{H}_{2} \mathrm{O}\right)_{n}\right]^{+}$を形成しにくく, (6) $\left[\mathrm{MSi}(\mathrm{OH})_{4}\left(\mathrm{H}_{2} \mathrm{O}\right)_{n}\right]^{2+}$ を形成しやすい，一方で, $\mathrm{Ca}^{2+}$ は負 
Table 5 Identified species in a $1 \mathrm{mM}$ silicic acid and $1 \mathrm{mM} \mathrm{MCl}_{2}$ solution in the positive ion mode

a) $\mathrm{M}=\mathrm{Mg}, \mathrm{Ca}, \mathrm{Sr}, \mathrm{Ba}$

\begin{tabular}{clll}
\hline Metal & \multicolumn{1}{c}{ species } & \multicolumn{1}{c}{$m / z$} \\
\hline \multirow{2}{*}{$\mathrm{Mg}$} & {$\left[\mathrm{MOSi}(\mathrm{OH})_{3}\left(\mathrm{H}_{2} \mathrm{O}\right)_{n}\right]^{+}$} & $(n=2-5)$ & $155,173,191,209$ \\
& {$\left[\mathrm{MSi}(\mathrm{OH})_{4}\left(\mathrm{H}_{2} \mathrm{O}\right)_{n}\right]^{2+}$} & $(n=5-8)$ & $105,114,123,132$ \\
$\mathrm{Ca}$ & {$\left[\mathrm{MOSi}(\mathrm{OH})_{3}\left(\mathrm{H}_{2} \mathrm{O}\right)_{n}\right]^{+}$} & $(n=2-4)$ & $171,189,207$ \\
& {$\left[\mathrm{MSi}(\mathrm{OH})_{4}\left(\mathrm{H}_{2} \mathrm{O}\right)_{n}\right]^{2+}$} & $(n=3-7)$ & $95,104,113,122,131$ \\
\multirow{2}{*}{$\mathrm{Sr}$} & {$\left[\mathrm{MOSi}(\mathrm{OH})_{3}\left(\mathrm{H}_{2} \mathrm{O}\right)_{n}\right]^{+}$} & $(n=2-4)$ & $219,237,255$ \\
& {$\left[\mathrm{MSi}(\mathrm{OH})_{4}\left(\mathrm{H}_{2} \mathrm{O}\right)_{n}\right]^{2+}$} & $(n=2-6)$ & $110,119,128,137,146$ \\
$\mathrm{Ba}$ & {$\left[\mathrm{MOSi}(\mathrm{OH})_{3}\left(\mathrm{H}_{2} \mathrm{O}\right)_{n}\right]^{+}$} & $(n=3)$ & 287 \\
& {$\left[\mathrm{MSi}(\mathrm{OH})_{4}\left(\mathrm{H}_{2} \mathrm{O}\right)_{n}\right]^{2+}$} & $(n=2-8)$ & $135,144,153,162,171,180,189$ \\
\hline
\end{tabular}

b) $\mathrm{M}=\mathrm{Mn}, \mathrm{Fe}, \mathrm{Co}, \mathrm{Ni}, \mathrm{Cu}, \mathrm{Zn}$

\begin{tabular}{|c|c|c|c|}
\hline Metal & species & & $m / z$ \\
\hline $\mathrm{Mn}$ & $\begin{array}{l}{\left[\mathrm{MOSi}(\mathrm{OH})_{3}\left(\mathrm{H}_{2} \mathrm{O}\right)_{n}\right]^{+}} \\
{\left[\mathrm{MSi}(\mathrm{OH})_{4}\left(\mathrm{H}_{2} \mathrm{O}\right)_{n}\right]^{2+}}\end{array}$ & $(n=2-4)$ & $\begin{array}{r}186,204,222 \\
-\end{array}$ \\
\hline $\mathrm{Fe}$ & $\begin{array}{l}{\left[\mathrm{MOSi}(\mathrm{OH})_{3}\left(\mathrm{H}_{2} \mathrm{O}\right)_{n}\right]^{+}} \\
{\left[\mathrm{MSi}(\mathrm{OH})_{4}\left(\mathrm{H}_{2} \mathrm{O}\right)_{n}\right]^{2+}}\end{array}$ & $(n=1-5)$ & $169,187,205,223,241$ \\
\hline Co & $\begin{array}{l}{\left[\mathrm{MOSi}(\mathrm{OH})_{3}\left(\mathrm{H}_{2} \mathrm{O}\right)_{n}\right]^{+}} \\
{\left[\mathrm{MSi}(\mathrm{OH})_{4}\left(\mathrm{H}_{2} \mathrm{O}\right)_{n}\right]^{2+}}\end{array}$ & $\begin{array}{l}(n=2-4) \\
(n=6-8)\end{array}$ & $\begin{array}{l}190,208,226 \\
131.5,140.5,149.5\end{array}$ \\
\hline $\mathrm{Ni}$ & $\begin{array}{l}{\left[\mathrm{MOSi}(\mathrm{OH})_{3}\left(\mathrm{H}_{2} \mathrm{O}\right)_{n}\right]^{+}} \\
{\left[\mathrm{MSi}(\mathrm{OH})_{4}\left(\mathrm{H}_{2} \mathrm{O}\right)_{n}\right]^{2+}}\end{array}$ & $\begin{array}{l}(n=1-5) \\
(n=2,4,6,8)\end{array}$ & $\begin{array}{l}\text { 171, 189, 207, 225, } 243 \\
95,113,131,149\end{array}$ \\
\hline $\mathrm{Cu}$ & $\begin{array}{l}{\left[\mathrm{MOSi}(\mathrm{OH})_{3}\left(\mathrm{H}_{2} \mathrm{O}\right)_{n}\right]^{+}} \\
{\left[\mathrm{MSi}(\mathrm{OH})_{4}\left(\mathrm{H}_{2} \mathrm{O}\right)_{n}\right]^{2+}}\end{array}$ & $(n=2-4)$ & 194, 212, 230 \\
\hline $\mathrm{Zn}$ & $\begin{array}{l}{\left[\mathrm{MOSi}(\mathrm{OH})_{3}\left(\mathrm{H}_{2} \mathrm{O}\right)_{n}\right]^{+}} \\
{\left[\mathrm{MSi}(\mathrm{OH})_{4}\left(\mathrm{H}_{2} \mathrm{O}\right)_{n}\right]^{2+}}\end{array}$ & $(n=2-4)$ & 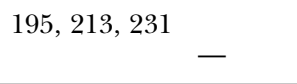 \\
\hline
\end{tabular}

$\square$ : overlapping species.

イオンモードにおいてケイ酸との錯体 $\left([\mathrm{Si}-\mathrm{Ca}]^{-}\right.$とする $)$ が検出され, 正イオンモードで (5) $\left[\operatorname{MOSi}(\mathrm{OH})_{3}\left(\mathrm{H}_{2} \mathrm{O}\right)_{n}\right]^{+}$ も (6) $\left[\mathrm{MSi}(\mathrm{OH})_{4}\left(\mathrm{H}_{2} \mathrm{O}\right)_{n}\right]^{2+}$ も検出された. $\mathrm{Mg}^{2+}$ 及び $\mathrm{Sr}^{2+}$ は (5) $\left[\mathrm{MOSi}(\mathrm{OH})_{3}\left(\mathrm{H}_{2} \mathrm{O}\right)_{n}\right]^{+}$も (6) $\left[\mathrm{MSi}(\mathrm{OH})_{4}\left(\mathrm{H}_{2} \mathrm{O}\right)_{n}\right]^{2+}$ 検 出された. $[\mathrm{Si}-\mathrm{Ca}]^{-}$は FAB-MS による測定で検出された化 学種と差異はなく, 本来の溶液中に存在している化学種と 考えられる. $[\mathrm{Si}-\mathrm{M}]^{-}$は $\mathrm{Na}^{+}$においても検出された。 二つ の金属で類似した值のパラメーターとして，イオン化した ときのサイズがほぼ同じことが挙げられる ${ }^{20)}$. 以上のこと から, ESI-MS のイオン化を経ても溶存化学種が検出され る安定性はイオンの大きさに依存し, 今回の実験条件で は, $\mathrm{Ca}^{2+}$ と $\mathrm{Na}^{+}$が安定にケイ酸錯体が検出されるに適当な イオンの大きさであったと考えた. 以下の実験 4 及び実験 5 では, 装置によるイオン化の条件を変化させ, $[\mathrm{Si}-\mathrm{Ca}]^{-}$ 化学種の安定性の確認及び, 新たに安定な化学種の探索や ケイ酸と金属元素の安定性について考察を行った.

$3 \cdot 5$ 実験 4 イオン化条件の変化（CDL 温度）

ESI-MS において，イオン化条件によっては不安定な化
Table 6 Identified silica and metals species in a $1 \mathrm{mM}$ silicic acid and $1 \mathrm{mM} \mathrm{MCl}_{2}$ solution in the negative ion mode

a) $\mathrm{M}=\mathrm{Ca}$

\begin{tabular}{lll}
\hline & $m / z$ & species \\
\hline monomer & 133 & {$\left[\mathrm{SiO}_{3}(\mathrm{OH}) \mathrm{Ca}\right]^{-}$} \\
dimer & 211 & {$\left[\mathrm{Si}_{2} \mathrm{O}_{4}(\mathrm{OH})_{3} \mathrm{Ca}\right]^{-}$} \\
& 249 & {$\left[\mathrm{Si}_{2} \mathrm{O}_{6}(\mathrm{OH}) \mathrm{Ca}_{2}\right]^{-}$} \\
\multirow{2}{*}{ tetramer } & 349 & {$\left[\mathrm{Si}_{4} \mathrm{O}_{5}(\mathrm{OH})_{4} \mathrm{Ca}\right]^{-}$} \\
\hline
\end{tabular}

b) $\mathrm{M}=\mathrm{Na}$

\begin{tabular}{lll}
\hline & $m / z$ & \multicolumn{1}{c}{ species } \\
\hline monomer & 161 & {$\left[\mathrm{SiO}_{4} \mathrm{Na}_{3}\right]^{-}$} \\
dimer & 177 & {$\left[\mathrm{Si}_{2} \mathrm{O}_{4}(\mathrm{OH})_{2} \mathrm{Na}^{-}\right.$} \\
& 239 & {$\left[\mathrm{Si}_{2} \mathrm{O}_{5}(\mathrm{OH})_{2} \mathrm{Na}_{3}\right]^{-}$} \\
trimer & 295 & {$\left[\mathrm{Si}_{3} \mathrm{O}_{5}(\mathrm{OH})_{5} \mathrm{Na}_{2}\right]^{-}$} \\
tetramer & 333 & {$\left[\mathrm{Si}_{4} \mathrm{O}_{7}(\mathrm{OH})_{5} \mathrm{Na}_{2}\right]^{-}$} \\
\hline
\end{tabular}


a)

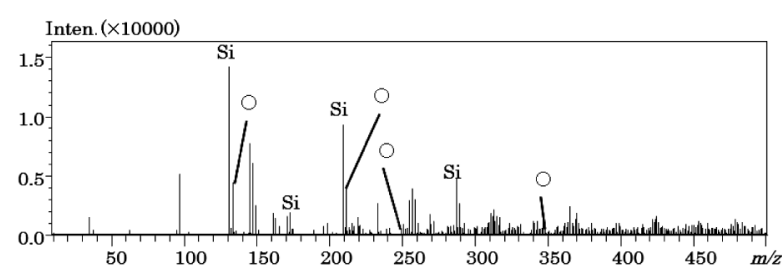

b)

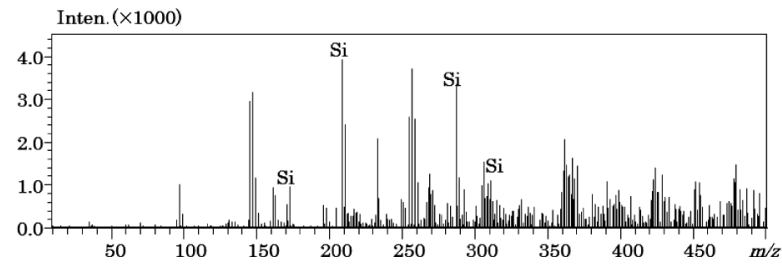

Fig. 5 ESI-MS spectra of $1.0 \mathrm{mM}$ silicic acid and 1.0 $\mathrm{mM} \mathrm{CaCl} 2$ solution in the negative ion mode

a) CDL tempature is $200{ }^{\circ} \mathrm{C}$; b) 300 . Marks of $\bigcirc$ mean calcium and silica $(m / z 133,211,249,349)$ species.

学種はより安定な化学種に変化する傾向がある. [ $\mathrm{Si}-\mathrm{Sr}]$ が存在しないのは，イオン化時に $[\mathrm{Si}-\mathrm{Sr}]^{+} に$ 変化している と考えた，もし $[\mathrm{Si}-\mathrm{Ca}]^{-}$が安定ではないときは，CDL 温 度や印加電圧の変化によって $[\mathrm{Si}-\mathrm{Ca}]^{-}$がなくなり, $[\mathrm{Si}-\mathrm{Ca}]^{+}$が生成することが考えられる. $[\mathrm{Si}-\mathrm{Ca}]^{-}$が安定で あれば，これらのイオン化条件によらず $[\mathrm{Si}-\mathrm{Ca}]^{-}$が存在す ることが分かる. CDL 温度を変化させた際のケイ酸+ $\mathrm{CaCl}_{2}$ 溶液のマススペクトルを Fig. 5 に示す. CDL 温度の 増加に伴い, 正イオンモード及び負イオンモードとも, 全 イオン強度（total ion count: TIC）が小さくなり, また, main peakが水和数の少ない化学種に変化した金属もあっ たことから, $\mathrm{CDL}$ の加熱温度を増加させることによってイ オン化の際の脱溶媒の作用が強く働き, 検出器まで到達す るイオンが減少したことが分かる.

負イオンモードに扔いて，バックグラウンドのピークが 顕著になり, 特に $m / z 250$ 以降では判別が困難であった. したがって， $m / z 250$ より低質量について新たに安定と考 えられる化学種を探索したが, 確認されなかった. しかし $3 \cdot 2 \cdot 2$ で示した $[\mathrm{Si}-\mathrm{Ca}]^{-}$化学種は, CDL 温度を 200〜 $300{ }^{\circ} \mathrm{C}$ に上げたにもかかわらず検出された. 正イオンモー ドでは， 2 族元素間の化学種の安定性の差が見られた.

$\mathrm{CDL}$ 温度 $200{ }^{\circ} \mathrm{C}$ から $300{ }^{\circ} \mathrm{C}$ にかけて, ケイ酸 $+\mathrm{MgCl}_{2}$ の溶液では顕著に (6) $\left[\mathrm{MgSi}(\mathrm{OH})_{4}\left(\mathrm{H}_{2} \mathrm{O}\right)_{n}\right]^{2+}$ よりも (5) $\left[\operatorname{MgOSi}(\mathrm{OH})_{3}\left(\mathrm{H}_{2} \mathrm{O}\right)_{n}\right]^{+}$の強度が高くなり, main peakが (3) $\left[\mathrm{Mg}\left(\mathrm{H}_{2} \mathrm{O}\right)_{8}\right]^{2+}\left(m / z\right.$ 84) から (2) $\left[\mathrm{Mg}(\mathrm{OH})\left(\mathrm{H}_{2} \mathrm{O}\right)_{3}\right]^{+}$ $\left(m / z\right.$ 95) に変化した。この現象が確認されたのは $\mathrm{Mg}^{2+}$ の みであり, $\mathrm{Ca}^{2+}, \mathrm{Sr}^{2+}, \mathrm{Ba}^{2+}$ では $200 \sim 300{ }^{\circ} \mathrm{C}$ にかけて 2 価の化学種が比較的高い強度を示した。このことから, ケ
イ酸 $+\mathrm{MgCl}_{2}$ の溶液では $\mathrm{CDL}$ 温度が高くなることによっ て, ESI-MS のイオン化時の加水分解またはプロトン脱離 などの作用が低温度のときよりも強く働き， 2 価の化学種 が状態を保てずに 1 価の化学種になる以下の反応が生じた と考えられる。

$$
\left[\mathrm{MSi}(\mathrm{OH})_{4}\left(\mathrm{H}_{2} \mathrm{O}\right)_{n}\right]^{2+} \rightarrow\left[\mathrm{M}\left(\mathrm{H}_{2} \mathrm{O}\right)_{n}\right]^{2+}+\mathrm{Si}(\mathrm{OH})_{4}
$$

または，

$$
\begin{aligned}
& \quad\left[\mathrm{MSi}(\mathrm{OH})_{4}\left(\mathrm{H}_{2} \mathrm{O}\right)_{n}\right]^{2+} \\
& \quad \rightarrow\left[\mathrm{M}\left(\mathrm{H}_{2} \mathrm{O}\right)_{n}\right]^{2+}+\left[\mathrm{SiO}(\mathrm{OH})_{3}\right]^{-}+\mathrm{H}^{+} \\
& {\left[\mathrm{M}\left(\mathrm{H}_{2} \mathrm{O}\right)_{n}\right]^{2+}+\mathrm{H}_{2} \mathrm{O} \rightarrow\left[\mathrm{M}(\mathrm{OH})\left(\mathrm{H}_{2} \mathrm{O}\right)_{n}\right]^{+}+\mathrm{H}^{+}}
\end{aligned}
$$

金属の加水分解定数で比較すると, $\mathrm{Mg}^{2+}$ は 2 族元素のなか で最も加水分解定数 ${ }^{19}$ が大きく, 遷移金属元素に次ぐ值で あり, CDL 温度の変化によって金属イオンの性質の差を反 映させた結果が得られた.

\section{$3 \cdot 6$ 実験 5 イオン化条件の変化（印加電圧）}

印加電圧を変化させた際のケイ酸 $+\mathrm{CaCl}_{2}$ 溶液のマスス ペクトルを Fig. 6 に示す. 印加電圧の増加に伴い, 正イオ ンモードでは TIC が大きくなり，負イオンモードでは $(-5.0 \mathrm{kV}$ から $-3.0 \mathrm{kV}$ にかけて) コロナ放電が抑えられ たため，TICが小さくなった，TICの值に変化はあったも のの, 化学種の相対強度に大きな変化はなく, 新たに安定

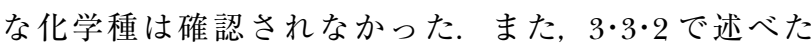
$[\mathrm{Si}-\mathrm{Ca}]^{-}$化学種は印加電圧の変化によらず検出された.

\section{4 結 言}

金属塩化物の溶液 $\left(\mathrm{MCl}_{2}\right.$ 溶液 $)$ 及びヶイ酸と $\mathrm{MCl}_{2}$ の溶 液を ESI-MS を用いて測定し, 検出された化学種を比較す ることで, ESI-MS 内に扔ける反応機構を推測し, 錯体の安 定性について新たな情報を得た．ESI-MS の正イオンモー ドにおいて，2 族元素よりも遷移金属元素の方が加水分解 しやすいという金属元素の性質の差を示す結果が得られ， ESI-MS を用いた測定により，溶液の状態を反映する結果 が得られることが確認された。 また, $\mathrm{MCl}_{2}$ 溶液にケイ酸を 添加した溶液においても，金属元素の性質の差を反映した 結果が得られ，さらに，2族元素間でケイ酸と錯形成しゃ すい化学種が異なることが確認された，負イオンモードで は, $\mathrm{Ca}^{2+}$ 及び $\mathrm{Na}^{+}$とケイ酸の錯体が確認され, これらの元 素とケイ酸の錯体は FAB-MS を用いた測定においても確認 されていることから，溶存化学種であると考えた．このこ とから，ESI-MS 内に打けるケイ酸イオンと金属イオンの 
a)

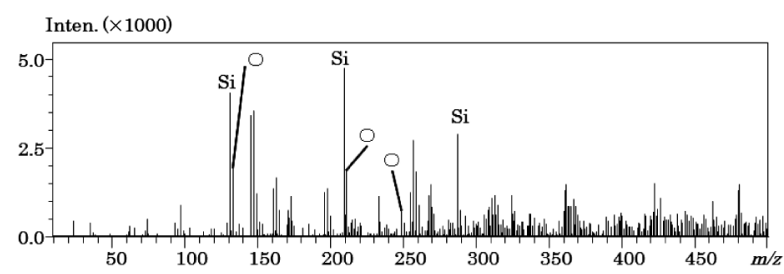

b)

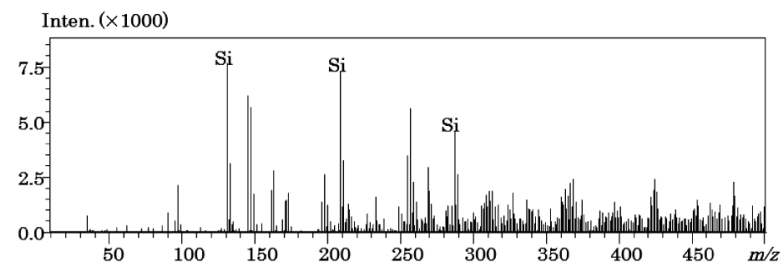

c)

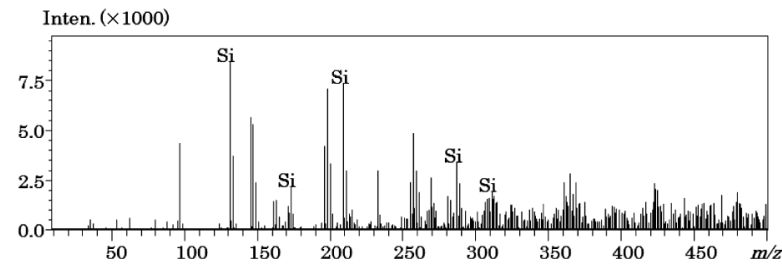

Fig. 6 ESI-MS spectra of $1.0 \mathrm{mM}$ silicic acid and 1.0 $\mathrm{mM} \mathrm{CaCl}{ }_{2}$ solution in the negative ion mode

a) Probe voltage is $-5.0 \mathrm{kV}$; b) -4.0 ; c) -3.0 .

反応機構を推測し, $\mathrm{Ca}^{2+}$ 及び $\mathrm{Na}^{+}$はケイ酸と安定な錯体を 形成すると考えた，さらに，イオン化の条件（CDL 温度, 印加電圧）を変えて測定を行い，錯体の安定性の確認をし た．今後は，使用する金属にランタノイドやほかの性質を 持つ金属を用いてさらに安定性の違いについての情報を得 る必要がある. 以上のように, ESI-MS 内のケイ酸 $+\mathrm{MCl}$ 溶 液における化学種の検出機構や, 気相反応による生成化学 種または溶存化学種であるかの情報を得ることで, ESI-MS を用いた低濃度のケイ酸試料の溶存状態をより詳細にでき ると考える.
謝 辞

本研究は, 平成 25 年度ボイラー・圧力容器等研究助成 (社団法人日本ボイラー協会), 公益財団法人ソルト・サイ エンス財団 平成 26 年度研究助成（助成番号 1408）の一 部によって行われました。同研究費に感謝致します。

\section{文献}

1) 杉田 創, 山本雅弘：日本地熱学会誌，21，359 (1999).

2) 増子 昇, 虫明克彦: 生産研究, 29, 96 (1977).

3) 佐伯和利: 粘土科学, 45, 90 (2006).

4) A. Samadi-Maybodi, S. Ehsani, H.-R. Bijanzadeh, : J. Solution Chem., 37, 413 (2007).

5) R. J. Hook : J. Non-Cryst. Solids., 195, 1 (1996).

6) N. goudarzi : Appl. Magn. Reson., 44, 469 (2013).

7) M. Haouas, L. Lakiss, C. Martineau, J. El Fallah, V. Valtchev, F. Taulelle : Microporous Mesoporous Mater., 198, 35 (2014).

8) A. Aerts, M. Haouas, T. P. Caremans, L. R. A. Follens, T. S. van Erp, F. Taulelle, J. Vermant, J. A. Martens, C. E. A. Kirschhock: Chem.-Eur. J., 16, 2764 (2010).

9) M. Tanaka, K. Takahashi : Anal. Chim. Acta, 411, 109 (2000).

10) K. Eggers, T. Eichner, J. Woenckhaus : Int. J. Mass Spectrom., 244, 72 (2005).

11) S. A. Pelster, W. Schrader, F. Schüth : J. Am. Chem. Soc., 128, 4310 (2006).

12) T. Urabe, M. Tanaka, S. Kumakura, T. Tsugoshi : $J$. Mass Spectrom., 42, 591 (2007).

13) 高橋茉莉子, 田中美穂: 分析化学 (Bunseki Kagaku), 61, 1049 (2012).

14) T. Oikawa, T. Urabe, S. Kawano, M. Tanaka : J. Solution Chem., 40, 1094 (2011).

15) M. E. Simonsen, E. G. Søgaard : Int. J. Mass Spectrom., 285, 78 (2009).

16) M. E. Simonsen, C. Sønderby, E. G. Søgaard : J. SolGel Sci. Technol., 50, 372 (2009).

17) 田中美穂：分析化学 (Bunseki Kagaku), 53, 561 (2004).

18) K. Hiraoka : J. Mass Spectrom. Soc. Jpn., 58, 139 (2010).

19) R. M. Smith, A. E. Martell : “Critical stability constant”, p. 1 (1976), (Plenum Press, New York).

20) 大滝仁志, 田中元治, 舟橋重信 : 溶液反応の化学, p. 214 (1977), (学会出版センター). 


\title{
Elucidation of Reaction Mechanism for Complex Formation of Silicate and Metal Ions in ESI-MS
}

\author{
Hiroka ARIGA ${ }^{1}$ and Miho TANAKA ${ }^{* 1}$ \\ * E-mail : mihotnk@kaiyodai.ac.jp \\ ${ }^{1}$ Graduate school of Marine Science and Technology, Tokyo University of Marine Science and Technology, \\ 4-5-7, Konan, Minato-ku, Tokyo 108-8477
}

(Received December 11, 2014; Accepted January 16, 2015)

Silicate and metal species with both positive and negative ions in solutions were examined by electrospray ionization mass spectrometry (ESI-MS). Comparing with detected species in chloride solutions of group-2 elements and transition metals $\left(\mathrm{MCl}_{2}\right)$, and silicate solutions with $\mathrm{MCl}_{2}$, the reaction mechanism of the silicate and metal complexes through the ESI-MS was elucidated, and the information on their stability was obtained. In the positive ion, it was shown that in both $\mathrm{MCl}_{2}$ solutions and silicate solutions with $\mathrm{MCl}_{2}$ that bivalent transition metals ( $\mathrm{Mn}, \mathrm{Fe}, \mathrm{Co}, \mathrm{Ni}, \mathrm{Cu}, \mathrm{Zn})$ were more easily hydrolyzed than group-2 elements $(\mathrm{Mg}, \mathrm{Ca}$, $\mathrm{Sr}, \mathrm{Ba})$. It was also confirmed that $\mathrm{Ca}^{2+}$ made the most stable complex with silicate ion among $\mathrm{Mg}^{2+}, \mathrm{Ca}^{2+}, \mathrm{Sr}^{2+}$ and $\mathrm{Ba}^{2+}$. Concerning the negative ion, $\mathrm{Ca}^{2+}$ and $\mathrm{Na}^{+}$were found to make stable complexes with silicate. Furthermore, the stability of $\mathrm{M}^{2+}$ with silicate were examined by controlling the ionization conditions, such as the CDL temperature or the ESI probe voltage, for both positive and negative ions. The results showed that, the silicate complexes with $\mathrm{Ca}^{2+}$ and $\mathrm{Na}^{+}$were identified by negative ions. These negative complexes are concluded to exist as they were as original species in the solutions. From these results, the stability between silicate and $\mathrm{M}^{2+}$ depends on their ionic size. Thus, $\mathrm{Ca}^{2+}$ and $\mathrm{Na}^{+}$with silicate possess high stability.

Keywords: silicate ion; ESI-MS; stability; metal ions. 